\title{
Nursing students' experiences, perceptions and behavior in a flipped-classroom anatomy and physiology course
}

\author{
Thomas R. Mikkelsen * \\ VIA E-Learning \& Media, Center for Applied Research \& Development and School of Nursing, Campus Holstebro, VIA \\ University College, Holstebro, Denmark
}

Received: May 5, 2015

DOI: $10.5430 /$ jnep.v5n10p28

\author{
Accepted: July 3, 2015 \\ Online Published: July 12, 2015 \\ URL: http://dx.doi.org/10.5430/jnep.v5n10p28
}

\begin{abstract}
Objective: The aim of this study was to explore nursing students' experiences, perceptions and behavior during a course on kidney and urinary system anatomy and physiology designed according to the flipped-classroom approach. In flipped-classroom teaching, students prepare for class by engaging with teacher-produced learning material, typically videos. This frees up time in class, which can instead be spent on various student-centered, active-learning activities. Only very few studies on the use of flipped classroom in nursing education have been published.

Methods: Videos and active-learning activities were developed and used in a course with forty-eight first-year, first-semester nursing students at the School of Nursing, Campus Holstebro, VIA University College, Denmark. After completing the course, students were invited to participate in a survey. In addition, students' use of videos was tracked during the course.

Results: Students expressed a very high degree of satisfaction with the eight videos assigned, which they generally watched on the day before class. The videos helped them acquire knowledge and prepare for in-class, active-learning activities. Twenty-six percent of the students believed that the videos were better than face-to-face lectures with regard to learning outcome, $56 \%$ felt they were of equal benefit, and only $18 \%$ benefited most from face-to-face lectures. Only a small minority (18\%) preferred traditional teaching over flipped classroom teaching, $41 \%$ preferred flipped classroom and $41 \%$ did not prefer one approach over the other.

Conclusions: These results demonstrate that the flipped classroom is a valuable teaching approach in nursing education which can result in a high level of both student satisfaction and self-reported learning outcome.
\end{abstract}

Key Words: Flipped classroom, Nursing education, Anatomy and physiology, Video lecture, Active learning

\section{INTRODUCTION}

Traditional lectures are still a predominant instructional strategy in many parts of higher education. But this use of class time has been criticized by many as ineffective. ${ }^{[1]}$ Students' attention drops quickly, they too often feel disengaged, the lecture pace does not suit all students, and retention of the material presented in typical lectures is low. ${ }^{[2-4]}$ There is an ongoing discussion in the literature about the need to rethink classroom practices, with a special focus on activities where learners are involved as active participants. ${ }^{[2]}$ In nursing, there has been a call for a radical transformation of nursing education involving educators designing learning experiences that enhance educational quality and ensure that graduates are prepared for today's complex nursing prac-

\footnotetext{
*Correspondence: Thomas R. Mikkelsen; Email: trm@via.dk; Address: School of Nursing, Campus Holstebro, VIA University College, Gl. Struervej 1, DK-7500 Holstebro, Denmark.
} 
tice. ${ }^{[5,6]}$

One promising alternative teaching strategy is flipped classroom. In the flipped-classroom pedagogical approach, the traditional lecture is substituted by a format where students watch video lectures before class and precious class time is spent on active-learning activities such as individual and small group exercises, application activities, case studies, discussions, and role playing. This inverted approach engages the students actively in course content during class time, and thus students are no longer inactive recipients as typically seen in traditional lectures. ${ }^{[7-9]}$

Flipped-classroom teaching furthers student engagement in several ways: They can watch video lectures before class, they can participate in varied in-class collaborative and activelearning activities, or they can interact with the instructor during these activities. Therefore, the method has the potential to address the different learning styles of students. ${ }^{[1]}$ Flipped classroom also entails a role change for instructors, with much more instructor-student interaction. Rather than being primarily a conveyor of information, the instructor acts as a facilitator and guide, giving personal feedback to individual students, and thus making a more collaborative and cooperative contribution to the teaching process. ${ }^{[3,9,10]}$

The method is believed to have the potential to enhance student learning, both because students are actively engaged in the learning process, and because the instructor has more time to interact with students individually or in small groups. Through this individualization of the educational encounter, the instructor has a much better chance of meeting the varied learning needs of the students and identifying and correcting errors of understanding. ${ }^{[7,9]}$ For example, students that are hesitant in the large classroom setting might be more likely to seek the instructor's assistance in a flipped-classroom setting. ${ }^{[3]}$ Flipped classroom is now a growing movement also in higher education, ${ }^{[7,10]}$ and many universities and colleges have embraced the approach. ${ }^{[11]}$

There is a general need for evidence to support creative teaching methods such as flipped classroom. ${ }^{[8]}$ However, research concerning flipped classroom is still very limited, ${ }^{[1,3]}$ and this paucity of research literature is also evident with regard to the use of flipped classroom in nursing education, ${ }^{[12,13]}$ in part because nursing education has only recently embraced the method. ${ }^{[14]}$ A search in major nursing education journals and in CINAHL has confirmed this: Only very few studies on the use of flipped classroom in nursing education have been published to date.

Misseldine et al. ${ }^{[6]}$ compared three different teaching modalities, one of them flipped classroom, in two adult health

Published by Sciedu Press courses for baccalaureate nursing students. They found that flipped-classroom teaching resulted in significantly better exam scores than the two other modalities investigated (traditional lecture only and lecture capture as an addition to traditional lecture). Interestingly, Misseldine et al. also found that students who had experienced the flipped-classroom method, were significantly less satisfied with the course than students who had experienced the other two teaching methods.

Critz and Knight ${ }^{[4]}$ used flipped-classroom teaching in two classes of graduate students $(n=20)$ taking a pediatric course in a Family Nurse Practitioner program. Using an online survey to measure student satisfaction, they reported that $85 \%$ of the students felt it extremely or very worthwhile to listen to the pre-recorded lectures. A similar level of satisfaction was expressed by students regarding the in-class activities (working through case scenarios).

Schwartz ${ }^{[9]}$ used flipped classroom in a statistics course in a nursing education Ph.D. program. Students $(n=9)$ answered a questionnaire regarding the effect of the flippedclassroom format on their learning and engagement. Results indicated a high degree of satisfaction with the format, including recorded lectures and in-class activities, and Schwartz concluded that the flipped-classroom format is very effective in supporting student learning.

The use of videos which students are expected to watch before class is typically an integral part of flipped-classroom teaching. Access to such videos enables the students to take control of the presentation of course content. Students can watch each video lecture at their preferred time and place, as often as they want, at a pace that suits the individual student - pausing, rewinding and fast-forwarding as necessary. This is a potential advantage in comparison to traditional lectures, where students cannot stop to think, and where they might miss important points while taking notes. ${ }^{[3,10]}$ It is the students' responsibility to watch the videos before class. If they fail to do so, they face the risk of not being able to participate fully in the in-class activities since these are carefully integrated with the content of the videos in the flipped-classroom approach. ${ }^{[10]}$ It is typically recommended that the videos produced for flipped-classroom use should be short (5 to 30 minutes) to avoid losing students' attention $^{[1,3,8,15,16]}$ although some authors report using videos of a longer duration. ${ }^{[12]}$ Smith and McDonald ${ }^{[15]}$ further recommend that each recording (video) should contain only one topic.

The present study aimed to investigate flipped-classroom teaching in nursing education with a special focus on students' use of videos and students' experiences with and perceptions of the flipped-classroom approach, including their 
opinions about the effect of the approach on their learning outcome.

\section{METHOD}

\subsection{Participants and setting}

The study was carried out with a class of forty-eight firstyear nursing students (class SHF2014) at the School of Nursing, Campus Holstebro, VIA University College, Denmark. As part of a full anatomy and physiology course, these students took a course on kidney and urinary system anatomy and physiology designed according to the flippedclassroom approach. After the course, students were asked to answer an anonymous questionnaire containing questions about how they had used the videos that were part of the flipped-classroom teaching approach and questions about their experiences and perceptions of the flipped classroom.

\subsection{Videos and course plan}

To conduct the flipped-classroom teaching, a number of videos containing short lectures presenting core course content in a highly condensed form were developed and produced. First, eight MS PowerPoint files containing text, drawings and simple animations about kidney and urinary system anatomy and physiology were developed. Each of the files focused on one topic, as recommended by Smith and McDonald. ${ }^{[15]}$ To produce the videos, each of these files was presented as a slide show with narration by the author, and screen (presentation) and sound (narration) was captured using Camtasia (TechSmith). The resulting eight videos were uploaded to YouTube immediately after production (see Table 1).

Table 1. Videos produced and used in the flipped-classroom course on kidney and urinary system anatomy and physiology

\begin{tabular}{lll}
\hline Video & Subject & Duration \\
\hline 1 & Kidney and urinary system anatomy & 5 min $35 \mathrm{~s}$ \\
2 & Overview of nephron function & 4 min $15 \mathrm{~s}$ \\
3 & Nephron filtration & $8 \mathrm{~min} 45 \mathrm{~s}$ \\
4 & Nephron reabsorption & $6 \mathrm{~min} 20 \mathrm{~s}$ \\
5 & Nephron secretion & 2 min $59 \mathrm{~s}$ \\
6 & The composition of urine & 3 min $24 \mathrm{~s}$ \\
7 & The renal threshold for glucose and glycosuria & 4 min $10 \mathrm{~s}$ \\
8 & Why you need functioning kidneys & 3 min $58 \mathrm{~s}$ \\
\hline
\end{tabular}

All eight videos were made available to the participating students eight days before the first lessons in the course. On the same day, a course plan was made available to the students in the institution's learning management system. The course had a total of 10 hours' class time spread over four days $(2+2+3+3)$ over a period of two weeks. The course plan contained specific information about

- which videos the students were expected to watch before class on each of the four days with lessons
- which pages in the textbook they were expected to read before class

- the activities that would be taking place in class on each of the four days.

An excerpt of the course plan is shown in Table 2. Students were asked to watch videos 1,2 and 3 before the first day with lessons, videos 4,5 and 6 before the second day, and videos 7 and 8 before the third day with lessons. No videos were assigned for the fourth and last day with lessons.

Table 2. Excerpt of course plan for the flipped-classroom course on kidney and urinary system anatomy and physiology

\begin{tabular}{llll}
\hline Date, time & How you should prepare for class & Activities in class & Textbook pages \\
\hline June 32014 & Read the assigned textbook pages. & We are going to work on the function of nephrons. & Pp 229-231. \\
9-11 a.m. & Watch the following videos: & Activities: & Pp 233-241. \\
& Video 1 (link) & 1) Short introduction to course content and today's \\
& Video 2 (link) & activities. \\
& Video 3 (link) & 2) Group exercises on filtration and the filtration \\
& & mechanism. & 3) Joint review of exercises. \\
\hline
\end{tabular}




\subsection{Active-learning activities}

Engaging in the development of flipped-classroom teaching required a redesign of classroom activities to make possible a much larger focus on active-learning and student-centered activities. Thus, a number of exercises, problems, and assignments were developed for use in class. Each activity was developed in accordance with the flipped-classroom concept, as previously described. To illustrate, in one group activity, students who had been asked to prepare for class by watching specific videos on nephron function were given the task of describing what would happen to different molecules and ions normally present in the blood (e.g., glucose, albumin, amino acids, $\mathrm{Na}^{+}$, and $\mathrm{K}^{+}$) when they enter the kidneys. In this activity, students had to engage actively with important concepts such as filtration, reabsorption and secretion.

\subsection{Online questionnaire}

An anonymous online questionnaire containing 12 multiple select questions and 9 free response questions was produced with Quia (IXL Learning) and made available to all partici pating students immediately after the fourth and last class session of the course. Reminders were sent to students after 4 and 13 days, and the questionnaire was closed on day 15 .

\subsection{Video usage}

Students' usage of the eight videos (e.g., number of times played and number of minutes watched) was tracked using the statistics data on YouTube.

\section{RESUlts}

\subsection{Students' video usage}

Thirty-four of the forty-eight participating students $(71 \%)$ answered the questionnaire.

Twenty-nine of the respondents $(85 \%)$ reported that they had watched all eight videos during the course. The remaining five respondents had watched only some of the videos. No students reported technical problems.

Most of the respondents (twenty-eight students; 82\%) said that they had watched all the assigned videos before class. Twenty-one respondents $(62 \%)$ reported that they had watched most or all the videos only before class, not during or after class, whereas twelve $(35 \%)$ reported having watched most or all videos both before and after class.

Some representative examples of free responses to the questionnaire item regarding when videos were watched were: "I watched the videos before [class], then I had a better chance to understand what was said in class"; "It was really good to watch the videos before class since one had a better understanding in class"; and "I learned incredibly much from your videos. There's the possibility to pause, rewind as much as one needs. That gives a possibility for better understanding. If there's something you haven't understood, you ... can go home and watch the videos again".

When asked whether they had watched a whole video or part of it more than once, a majority of the respondents (twentyeight students; $82 \%$ ) said that they had done this to a high or to some degree. Similarly, a majority of respondents (twentysix students; $76 \%$ ) reported that they had paused a video and resumed playing later to a high or to some degree, and approximately half of the respondents (eighteen students; $53 \%$ ) said that they had jumped to a specific place in a video to watch selected content.

YouTube statistics data on video use revealed a typical pattern: Students consistently watched each of the eight videos primarily the day before the class to which the video was assigned. For example, Video 2 (Overview of nephron function), was played thirty-one times on June 2 - the day before the class time with activities specifically designed to correspond to the content of this video. On all other days during the course period, this video was only played from zero to four times (see Figure 1).

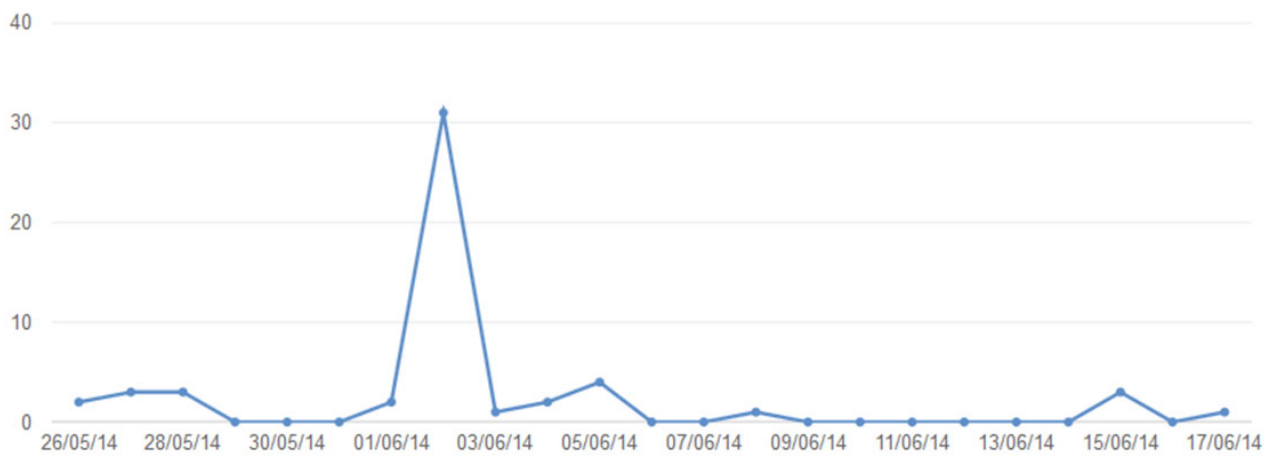

Figure 1. Number of times Video 2 (Overview of nephron function) was played during the course period. The video was made available to the students on May 26 (“26/05/14”), students were asked to watch the video before class time on June 3, and the last class time in the course was on June 16. Data from YouTube.com. 


\subsection{Student experiences and perceptions}

A number of items in the questionnaire examined students' experiences with and perceptions of the videos and of the flipped-classroom teaching approach. These items and the distribution of student responses are presented in Table 3 .

All respondents (thirty-four, 100\%) agreed to a large or to some extent that the videos helped them acquire knowledge about kidney and urinary system anatomy and physiology. Nearly all respondents (thirty-three students; 97\%) agreed to a large or to some extent that watching the assigned videos prepared them well for the ensuing in-class activities, and all respondents (100\%) agreed to a large or to some extent that there was a good connection between video content and in-class activities.

Table 3. Selected questionnaire items and students' responses

\begin{tabular}{|c|c|c|c|c|c|c|c|}
\hline Questionnaire item & \multicolumn{7}{|c|}{ Students' responses } \\
\hline $\begin{array}{l}\text { To what extent did watching the videos help you } \\
\text { acquire knowledge about kidney and urinary system } \\
\text { anatomy and physiology? }\end{array}$ & \multicolumn{2}{|c|}{ To a large extent } & $6(18 \%)$ & extent & \multicolumn{2}{|c|}{ To a small extent } & Not at all \\
\hline \multirow{2}{*}{$\begin{array}{l}\text { To what extent do you agree with the following } \\
\text { statement: “Watching the assigned videos before class } \\
\text { provided good preparation for the class activities"? }\end{array}$} & $\begin{array}{l}\text { Agree to a } \\
\text { large extent }\end{array}$ & \multicolumn{2}{|c|}{$\begin{array}{l}\text { Agree to } \\
\text { some extent }\end{array}$} & \multicolumn{2}{|c|}{$\begin{array}{l}\text { Neither agree } \\
\text { nor disagree }\end{array}$} & $\begin{array}{l}\text { Disagree to } \\
\text { some extent }\end{array}$ & $\begin{array}{l}\text { Completely } \\
\text { disagree }\end{array}$ \\
\hline & 25 (74\%) & \multicolumn{2}{|c|}{$8(24 \%)$} & \multicolumn{2}{|c|}{$1(3 \%)$} & 0 & 0 \\
\hline \multirow{2}{*}{$\begin{array}{l}\text { To what extent do you agree with the following } \\
\text { statement: "There was a good connection between the } \\
\text { content in the assigned videos and the class activities"? }\end{array}$} & $\begin{array}{l}\text { Agree to a } \\
\text { large extent }\end{array}$ & \multicolumn{2}{|c|}{$\begin{array}{l}\text { Agree to } \\
\text { some extent }\end{array}$} & \multicolumn{2}{|c|}{$\begin{array}{l}\text { Neither agree } \\
\text { nor disagree }\end{array}$} & $\begin{array}{l}\text { Disagree to } \\
\text { some extent }\end{array}$ & $\begin{array}{l}\text { Completely } \\
\text { disagree }\end{array}$ \\
\hline & 27 (79\%) & \multicolumn{2}{|c|}{7 (21\%) } & 0 & & 0 & 0 \\
\hline $\begin{array}{l}\text { How would you estimate your learning outcome of } \\
\text { lecturer video presentation of materials compared to } \\
\text { lecturer presentation of materials in the classroom? }\end{array}$ & \multicolumn{2}{|c|}{$\begin{array}{l}\text { Benefit most from } \\
\text { video presentation }\end{array}$} & \multicolumn{3}{|c|}{$\begin{array}{l}\text { Benefit most from } \\
\text { presentation in the } \\
\text { classroom }\end{array}$} & \multicolumn{2}{|c|}{$\begin{array}{l}\text { Benefit equally well from } \\
\text { the two forms of } \\
\text { presentation }\end{array}$} \\
\hline $\begin{array}{l}\text { Outside class, you have had two options for acquiring } \\
\text { knowledge about the function of nephrons, the } \\
\text { composition of urine and why well-functioning kidneys } \\
\text { are important: reading the textbook and watching the } \\
\text { eight videos. }\end{array}$ & \multicolumn{2}{|c|}{$\begin{array}{l}\text { The videos were not } \\
\text { important for my } \\
\text { acquisition of } \\
\text { knowledge }\end{array}$} & \multicolumn{3}{|c|}{$\begin{array}{l}\text { The videos had some } \\
\text { importance for my } \\
\text { acquisition of knowledge- } \\
\text { but the textbook was more } \\
\text { important }\end{array}$} & \multicolumn{2}{|c|}{$\begin{array}{l}\text { The videos had a large } \\
\text { importance for my } \\
\text { acquisition of knowledge- } \\
\text { larger than the importance } \\
\text { of the textbook }\end{array}$} \\
\hline $\begin{array}{l}\text { Which of the following statements best describes your } \\
\text { view of the importance of the videos for your } \\
\text { acquisition of knowledge, compared to the importance } \\
\text { of the textbook? }\end{array}$ & \multicolumn{2}{|l|}{0} & \multicolumn{2}{|c|}{$11(32 \%)$} & & $23(68 \%)$ & \\
\hline $\begin{array}{l}\text { Compare the following two teaching methods which } \\
\text { you have experienced in the nursing school: } \\
\text { Method A) The majority of class time is spent on } \\
\text { content presentation by the lecturer and a relatively } \\
\text { short amount of time is spent on assignments and other } \\
\text { activities. } \\
\text { Method B) A relatively small amount of class time is } \\
\text { spent on content presentation by the lecturer (because } \\
\text { content presentation takes places in videos), and most } \\
\text { of the time is spent on individual and group } \\
\text { assignments, exercises, and other activities. } \\
\text { Which method do you prefer? }\end{array}$ & \multicolumn{2}{|l|}{$6(18 \%)$} & \multicolumn{2}{|c|}{$14(41 \%)$} & $14(41$ & $\begin{array}{l}\text { prefer one } \\
\text { over the other }\end{array}$ & No opinion \\
\hline
\end{tabular}

There were nine free responses to the two questionnaire items concerning the use of videos for preparation and the connection between video content and in-class activities. Three examples are "It [watching the videos] gave a good prior understanding”; “It was nice with a form of 'lecture' you could watch when you liked/had time"; and "Once, I had only watched the videos before class, I had not had time to read in the textbook, but when I came to class, I found out that I understood everything ...”.

When asked to compare their learning outcome gained from 
watching the video presentations with that gained from watching traditional classroom presentations by the lecturer, nineteen students $(56 \%)$ said they benefited equally from the two presentation forms, nine students $(26 \%)$ said they benefited most from watching videos, and only six students (18\%) said they benefited most from classroom presentations.

Students were also asked to compare the videos and the textbook with regard to their relative importance for their learning. Two-thirds (twenty-three students, 68\%) chose the answer "The videos had a large importance for my acquisition of knowledge - larger than the importance of the textbook"; the remaining third (eleven students, 32\%) chose the answer "The videos had some importance for my acquisition of knowledge - but the textbook was more important".

Finally, students were asked to compare the traditional teaching approach they had previously experienced in anatomy and physiology - with most of the class time spent listening to the lecturer's presentation - with the flipped-classroom approach. Fourteen students $(41 \%)$ preferred flipped classroom, fourteen students $(41 \%)$ did not prefer one approach over the other, and only six students $(18 \%)$ preferred the traditional teaching approach.

\section{Discussion}

As previously stated, research about the flipped-classroom teaching approach is still very limited, ${ }^{[3]}$ and only a few studies regarding flipped classroom in nursing education have been carried out. ${ }^{[12-14]}$ Furthermore, published research has often focused on the effect of the method in terms of student performances at exams. Of the few previous studies investigating nursing students' perceptions and experiences of a flipped-classroom approach, some have been very small, with few students participating, ${ }^{[4,9]}$ and typically only a rather limited number of aspects have been investigated. ${ }^{[4,6,9]}$ Thus, the available knowledge about student behavior in a flippedclassroom course as well as about how students perceive flipped-classroom teaching and its elements is very limited.

In this study, nursing students' experiences, perceptions, and behavior in a flipped-classroom anatomy and physiology course were investigated to obtain further knowledge regarding students' use of videos, their perception of the benefit of videos, and their experiences with and perceptions of the teaching approach. Responses to an online questionnaire show that more than $80 \%$ of the students found the flippedclassroom teaching approach as good as or better than a traditional teaching approach, where most class time is used on lecturer presentation.

This high level of student satisfaction differs from results presented by Misseldine et al., ${ }^{[6]}$ which showed that nursing students who had participated in a flipped-classroom format course were less satisfied than students who had experienced two other teaching formats. It also seems very different from recently published results by Post et al., ${ }^{[17]}$ where a phenomenological study was carried out, exploring nursing students lived experience of the flipped-classroom teaching strategy. These researchers found that among the major themes to emerge from interviews with eighteen students were frustration, disconnect and depersonalization. In the study by Post et al., students were clearly not satisfied with the teaching method, but responded with discomfort and anxiety.

High levels of general student satisfaction with flippedclassroom teaching have been reported in two small studies in nursing education ${ }^{[4,9]}$ and in other disciplines, e.g., physical therapy education. ${ }^{[18]}$

From the available evidence, it is not possible to explain why the use of flipped classroom in nursing education can result in very different student experiences and satisfaction levels. But it is important to bear in mind that the flipped-classroom approach is only a framework. How it is practiced no doubt varies from setting to setting. For example, the videos used are very likely quite different with regard to content, presentation style and length, and there are probably also large variations with regard to the in-class activities used.

Questionnaire responses in the present study show that a large majority of the responding students 1) had watched all eight videos during the course, 2) had watched them as stipulated by the lecturer (specific videos before specific lessons), 3 ) had watched a video or part of it more than once, and 4) had made use of the possibility to pause and resume the playing of a video. Furthermore, YouTube statistics showed that the playing of the individual videos was concentrated on the day before the class meeting requiring student understanding of the video content.

This detailed insight into students' video usage in a flippedclassroom course has, to the best of the author's knowledge, not been reported before. The insight demonstrates that most students watched the videos as intended, and, interestingly, that many students actually made use of one of the purported advantages of videos, namely the ability to pause video lectures when necessary according to each student's learning need and preferred pace. ${ }^{[3,7]}$

The videos used in this study received high ratings from the students. All responding students (100\%) expressed that the videos helped them acquire knowledge. Just over half of the students said that their learning outcome gained from 
watching the videos was equal to their learning outcome gained from watching classroom presentations by the lecturer. Notably, one-quarter of the students (26\%) said their learning outcome gained from watching videos was larger than their learning outcome from classroom presentations. Furthermore, approximately two-thirds of the students found that the videos were more important for their acquisition of knowledge than the textbook used in the course.

These results clearly suggest that videos used in a flippedclassroom setting are of potentially great value to students. Similar results were found Gilboy et al. ${ }^{[1]}$ where the flipped classroom was implemented in undergraduate nutrition courses. Two-thirds of the students in this study preferred watching videos over face-to-face lectures.

One potential factor contributing to the students' high ratings regarding the value and importance of videos might be the relatively short duration of the videos in this study. It is often stressed in the literature that educational videos should not be too long. ${ }^{[1,3,8,15,16]}$ Nevertheless, videos of considerable duration - often more than one hour, and sometimes even more than two hours - are used in some flipped-classroom settings. Results from other studies show that such very long videos can result in lower student satisfaction. ${ }^{[18,19]}$ By using very short videos in this study, as recommended in the literature, it has probably been possible to avoid losing student attention, resulting in higher satisfaction. ${ }^{[15]}$

The fact that a majority of students found the videos more important than the textbook is rather surprising. It might reflect that many students find the textbook explanations difficult to understand, or that they simply found the videos more convenient, easier, and quicker to use, or a combination of both. In any case, it might be appropriate for the instructor to stress that the short video lectures are supplementary learning resources, not substitutes for the textbook.

Since the success of the flipped-classroom method is critically dependent on the integration of in-class and out-ofclass activities, ${ }^{[10]}$ the students' perceptions regarding such integration were also investigated. All responding students $(100 \%)$ agreed that there was a good connection between video content and in-class activities, and all but one agreed that watching the assigned videos was good preparation for the in-class activities. These results clearly suggest that the way videos and in-class activities were connected and (purposefully) integrated was successful.

Similar results have been reported in a study of pharmacy students' attitudes to and perceptions of a flipped-classroom model in a renal pharmacotherapy module, where a large majority of participating students expressed that the videos used prepared them for the class activities, and that viewing them was essential for their successful participation in in-class activities. ${ }^{[20]}$

There are several limitations to the present study. First of all, the study investigated only students' subjective experiences and perceptions. So when approximately one in four students report that their learning outcome from watching videos was larger than their learning outcome from classroom presentations, this reflects how students perceive their learning outcome. Whether their learning outcome was actually higher was not investigated in this study. Although the questionnaire had several free response questions, questionnaire results did not produce detailed information regarding which specific aspects of the videos, the in-class learning activities, and the flipped-classroom teaching actually led to the previously described high degree of satisfaction and perceived increased learning outcome. Such information could be very relevant in the design of future flipped-classroom courses. Fourteen of the 48 students who followed the course did not answer the questionnaire, despite two reminders. The author has no reason to believe that these students had experiences and perceptions that were significantly different from those who did answer the questionnaire, but it cannot be ruled out. Finally, even though this study demonstrates successful implementation of flipped-classroom teaching in terms of student satisfaction and self-perceived learning outcome, the results are not necessarily generalizable, as flipped-classroom teaching can take on many forms.

\section{CONClusion}

This study demonstrates that the flipped-classroom teaching approach in nursing education can result in a high level of student satisfaction. It also shows that short video lectures can be of significant value for nursing students. Flipped classroom is thus a promising alternative to traditional lectures in nursing education, with a large potential for engaging students better in the classroom setting.

\section{ACKNOWLEDGEMENTS}

The author would like to thank Alice Nissen, Karen Louise Møller and Hanne Wacher Kjærgaard for suggestions and discussions regarding questionnaire design and manuscript preparation.

\section{CONFlicts OF INTEREST Disclosure}

The author declares that there is no conflict of interest. 


\section{REFERENCES}

[1] Gilboy MB, Heinerichs S, Pazzaglia G. Enhancing Student Engagement Using the Flipped Classroom. Journal of Nutrition Education and Behavior. 2015; 47(1): 109-114. PMid:25262529 http: //dx.doi.org/10.1016/j.jneb.2014.08.008

[2] McLaughlin JE, Roth MT, Glatt DM, et al. The Flipped Classroom: A Course Redesign to Foster Learning and Engangement in a Health Professions School. Academic Medicine. 2014; 89(2): 236-243. PMid:24270916 http://dx .doi .org/10.1097/ACM. 0 000000000000086

[3] Clark KR. Flipping Out: A Trend in Radiological Science Education. Radiologic Technology. 2014; 85(6): 685-687. PMid:25002644

[4] Critz CM, Knight D. Using the Flipped Classroom in Graduate Nursing Education. Nurse Educator. 2013; 38(5): 210213. PMid:23969751 http://dx.doi.org/10.1097/NNE. 0 b013 e3182a0e56a

[5] Benner P, Sutphen M, Leonard V, et al. Educating Nurses: A call for radical transformation. Stanford, CA: Jossey-Bass; 2010.

[6] Misseldine K, Fountain R, Summers L, et al. Flipping the Classroom to Improve Student Performance and Satisfaction. Journal of Nursing Education. 2013; 52(10): 597-599. PMid:24044386 http://dx.doi.org/10.3928/01484834-20130919-03

[7] McDonald K, Smith CM. The Flipped Classroom for Professional Development. Part I. Benefits and Strategies. The Journal of Continuing Education in Nursing. 2013; 44(10): 437-438. PMid:24098988 http://dx.doi.org/10.3928/00220124-20130925-19

[8] Murray L, McCallum C, Petrosino C. Flipping the Classroom Experience: A Comparison of Online Learning to Traditional Lecture. Journal of Physical Therapy Education. 2014; 28(3): 35-41.

[9] Schwartz TA. Flipping the Statistics Classroom in Nursing Education. Journal of Nursing Education. 2014; 53(4): 199-206. PMid:24654591 http://dx.doi.org/10.3928/01484834-20140325-02

[10] EDUCAUSE Learning Initiative. 7 Things You Should Know About Flipped Classrooms. 2012 February 7. Available from: https: //net.educause.edu/ir/library/pdf/ELI7081.pdf
[11] Johnson L, Becker SA, Estrada V, et al. NMC Horizon Report: 2014 Higher Education Edition. Austin, Texas: The New Media Consortium.

[12] Schlairet MC, Green R, Benton MJ. The Flipped Classroom. Strategies for an Undergraduate Nursing Course. Nurse Educator. 2014; 39(6): 321-325. PMid:25290966 http://dx.doi.org/10.1097 /NNE. 0000000000000096

[13] Yensen J. Active Learning Flip with Interaction and Exploration (ALFIE) - a New Model. Online Journal of Nursing Informatics. 2014; 18(1). Available from: http://ojni.org/issues/?p=3089

[14] Della Ratta CB. Flipping the Classroom with Team-Based Learning in Undergraduate Nursing Education. Nurse Educator. 2015; 40(2): 71-74. PMid:25402712 http://dx.doi.org/10.1097/NNE. 000 0000000000112

[15] Smith CM, McDonald K. The Flipped Classroom for Professional Development. Part II. Making Podcasts and Videos. The Journal of Continuing Education in Nursing. 2013; 44(11): 486-487. PMid:24199640 http://dx.doi.org/10.3928/00220124-201 31025-93

[16] Hawks SJ. The Flipped Classroom: Now or Never? AANA Journal. 2014; 82(4): 262-269.

[17] Post JL, Deal B, Hermanns M. Implementation of a flipped classroom: Nursing students' perspectives. Journal of Nursing Education and Practice. 2015; 5(6): 25-30. http://dx.doi .org/10.5430/j nep.v5n6p25

[18] Boucher B, Robertson E, Wainner R, et al. "Flipping" Texas State University's Physical Therapist Musculoskeletal Curriculum: Implementation of a Hybrid Learning Model. Journal of Physical Therapy Education. 2013; 27(3): 72-77.

[19] Wong TH, Ip EJ, Lopes I, et al. Pharmacy Students' Performance and Perceptions in a Flipped Teaching Pilot on Cardiac Arrythmias. American Journal of Pharmaceutical Education. 2014; 78(10): Article 185 PMid:25657372 http://dx.doi.org/10.5688/ajpe7810185

[20] Pierce R, Fox J. Vodcasts and Active-Learning Exercises in a "Flipped Classroom" Model of a Renal Pharmacotherapy Module. American Journal of Pharmaceutical Education. 2012; 76(10): Article 196. PMid:23275661 http://dx.doi.org/10.5688/ajpe7610196 